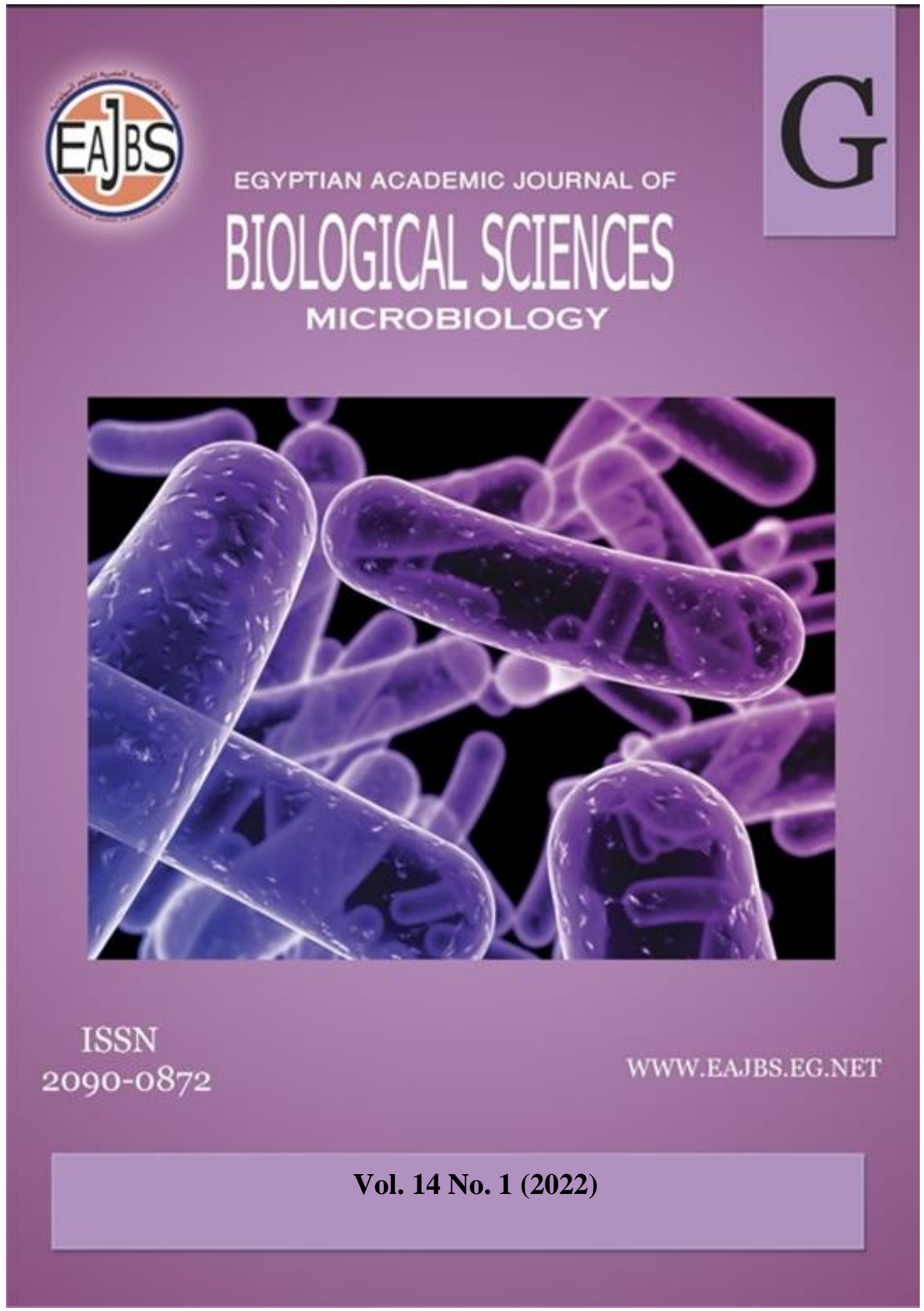

Citation: Egypt. Acad. J. Biolog. Sci. (G.Microbiolog) Vol.14 (1) pp.41- 45 (2022) DOI: 10.21608/EAJBSG.2022.219155 
Egypt. Acad. J. Biolog. Sci., 14(1):41-45(2022)

$\begin{gathered}\text { Egyptian Academic Journal of Biological Sciences } \\ \text { G. Microbiology }\end{gathered}$
ISSN: 2090-0872
https://eajbsg.journals.ekb.eg/

\section{Antibacterial Activity of Some Plant Extracts Against Multidrug-Resistant Pathogenic} Escherichia Coli.

Dina M. Baraka1, Yasser M. Ismael ${ }^{2}$, Hadeer A. Alnagar*1 and Mervat G. Hassan ${ }^{1}$

1- Department of Botany \& Microbiology, Faculty of science -Benha university

2-Department of Pathology, Faculty of Medicine -Benha university

$$
\text { *E.Mail: dodomery1989@gmail.com }
$$

\begin{tabular}{|c|c|}
\hline ARTICLE INFO & ABSTRACT \\
\hline Article History & In this study, we investigated the in-vitro effect of 11 medicinal \\
\hline Received: $3 / 1 / 2022$ & cts against 3 strains of multidrug resistance $E$ coli \\
\hline $9 / 1 / / 2022$ & tem and were given numbers $(1$, \\
\hline Available:3/2/2022 & $2,3)$ to dis \\
\hline Key & $\begin{array}{l}\text { d } 3 \text { showed complete resistance to } 8 \text { different types of } \\
\text { strain } 2 \text { showed } 11 \text { types of antibiotics out of } 11 \text { types of }\end{array}$ \\
\hline Patl & this study. \\
\hline $\begin{array}{l}\text { Escherichia coli, } \\
\text { medicinal plants, } \\
\text { multidrug-resistant }\end{array}$ & $\begin{array}{l}\text { Strain } 1 \text { showed sensitivity towards extracts of (Green tea, Fennel } \\
\text { seed, Pomegranate peel), strain } 2 \text { showed sensitivity towards (Fennel seed, } \\
\text { Sage leaves, Thyme leaves) extracts, and strain } 3 \text { showed sensitivity towards } \\
\text { (Green tea, Fennel seed, Pomegranate peel, Sage leaves, Thyme leaves). }\end{array}$ \\
\hline
\end{tabular}

\section{INTRODUCTION}

In recent years, Various Escherichia coli bacteria species have developed resistance to antibiotics (Palaniappan \& Holley 2010). this resistance has been existed due to a lot of reasons, but the most important reason has been the inappropriate consumption of antibiotics, whether by unnecessary use or by consuming wrong doses or types (Jastaniah,2014).

Knowing that Escherichia coli bacteria is the most common causative organism that is responsible for nosocomial infectious diseases in humans (Sligl et al., 2006).

It is known that at least there are 5 pathotypes of different $E$ coli bacteria that cause enteric diseases such as bacterial dysentery and diarrhea (Kokoska et al., 2002) also various types of extra gastric diseases like meningitis and Urinary tract infection (Kokoska et al., 2002). So researches were going in the direction of finding a new drug that could affect multidrugresistant bacterial strains, and due to the good reputation of the folkloric remedies that are based on medicinal plant extracts or their derivatives against infectious diseases, so medicinal plants has become a respectable alternative to antibiotics in fighting multidrug-resistant Escherichia coli a lot of studies have been putting medicinal plants on research to get authentic results, and a lot of discovered secondary medicinal products that hold antibacterial properties were discovered and proved their efficiency in fighting MDR bacteria. (Mahmoud et al., 2004).

Escherichia coli is a bacilli gram-negative non-forming spores, flagellated and facultative anaerobic bacteria, from the family Enterobacteriaceae (Kaper et al., 2004). 
E. coli is exciting in nonpathogenic form as normal flora of the human lower intestine as a commensal bacterium, in this form it causes no harm to human, but when it be found where else it develops virulence factors and become in its pathogenic form and cause disease in the place it was found in (Jain et al., 2005)

E. coli bacteria are lactose fermenting bacteria, it grows perfectly on Maconcky media and produces indole, it also gives a positive result in the catalase test and a negative result in the oxidase test, and some e coli subtypes ferment sorbitol (Kaper et al., 2004).

There are pathogenic 5 E. coli subtypes that are responsible for enteric diseases: enterotoxigenic Escherichia coli (ETEC), enter invasive Escherichia coli (EIEC), enteroaggregative Escherichia coli (EAEC), enteropathogenic Escherichia coli (EPEC), and, enterohemorrhagic Escherichia coli (EHEC), which also called Shiga toxin-producing Escherichia coli (STEC) which also could be referred to as EHEC/STEC (Nataro \& Kape, 1998).

They are been differentiated from each other by their $\mathrm{O}$ antigen which is located on the lipopolysaccharide outer membrane, $\mathrm{H}$ antigen which is located on the flagellum (Nataro \& Kape, 1998).

\section{MATERIALS AND METHODS}

In this study, we used eleven plants, plants were chosen based on their reputation by having a therapeutic effect against infectious diseases, different parts of each plant were used according to each plant folkloric way of preparation, plants parts were washed gently by distilled water and dried by fresh air at room temperature for three days, then each plant parts were carefully grounded by (Siemens-blender), After grounding, $10 \mathrm{~g}$ of each plant powder was weighed, placed in a sterilized Falcon tube and $50 \mathrm{ml}$ of methanol were added to each Falcon tube (Aneja et al., 2010).

Falcon tubes were covered tightly by their plastic lids, put in a shaking incubator for $48 \mathrm{~h}$, and then each supernatant was collected and was filtered through three layers of filtration paper then centrifuged at $5000 \mathrm{rpm}$ for $10 \mathrm{~min}$, each extract was concentrated to only $5 \mathrm{ml}$ in Vacuum via Heidolph VE-11 Rota evaporator below $40^{\circ} \mathrm{C}$. The final products were stored in sterilized containers at $4^{\circ} \mathrm{C}$ degrees. (Aneja et al., 2010).

\section{Studied Bacteria:}

Three E. coli bacterial strains were obtained from three different clinical specimens (urine, stool, sputum) collected from three different patients who were getting treatment in Benha Educational Hospital.

Every specimen was cultured on selective Macnky agar media and was identified as E. coli bacteria by Gram stain, morphological and biochemical tests. Then each strain was purified on nutrient agar media.

\section{Antibiotic Sensitivity Test:}

Studied bacterial strains were tested against 11antibiotics, by the Disk diffusion method, those Antibiotics were:

1. Meropenem (MEM10 $\mu \mathrm{g})$

2. Gentamicin $(\mathrm{GN} 10 \mu \mathrm{g})$

3. Moxifloxacin (MFX5 $\mu \mathrm{g})$

4. Tobramycin $(\mathrm{TMN} 10 \mu \mathrm{g})$

5. Levofloxacin $(\mathrm{LVX} 10 \mu \mathrm{g})$

6. Ofloxacin (OFX-5 $\mu \mathrm{g})$

7. Tetracycline (TS25 $\mu \mathrm{g})$

8. Trimethoprim+ Sulfamethoxazole (SXT $25 \mu \mathrm{g}$ )

9. Ciprofloxacin (CIP5 $\mu \mathrm{g})$

10. Amoxicilin $\backslash$ Glavulanic acid (AuG $30 \mu \mathrm{g})$

11. Ceftriaxone (CTX30 $\mu \mathrm{g})$ (CLSI), 2007)

Bacterial strains were cultured in Petri dishes with $20 \mathrm{ml}$ of Muller Hinton agar media by swapping technique, and then antibiotic disks were placed and incubated at $37^{\circ} \mathrm{C}$ for $24 \mathrm{~h}$.

\section{Plant Extracts Activity Test:}

Each bacterial strain was tested against the 11 plant methanolic extracts by disk diffusion method, 1 ML of each extract was inoculated to sterile paper discs $(6 \mathrm{~mm}$ 
in diameter), and was put in a sterile petri dish to dry in a sterilized condition, bacterial strains were inoculated to Petri dishes with $20 \mathrm{ml}$ of nutrient agar media by swapping technique then dried disks loaded with plant extracts were placed on cultures surfaces. then transferred to incubation at $37^{\circ} \mathrm{C}$ for $24 \mathrm{~h}$. (Cowan, 2009)

\section{Statistical Analysis:}

One-way ANOVA was carried out using the statistical analysis system (SAS/STAT ® 9.1) according to the software procedure's guide (SAS,2004) Citation: SAS Institute Inc.2004.SAS/STAT®9.1 User's Guide. Cary, NC: SAS Institute Inc.

\section{RESULTS AND DISCUSSION}

Three Escherichia coli bacterial strains were isolated from three different specimens from 3 different patients and were given numbers $(1,2,3)$ were identified as Escherichia coli bacteria, the three strains showed fermenting to lactose, positive catalase test negative oxidase test, grown on Mac agar media and produced indole.

All three bacterial strains were Gram-negative bacteria rod-shaped, formed white waxy colonies on nutrient agar media, and were confirmed as E. coli via VIETK2 system.

\section{Antibiotics Sensitivity Test:}

As shown in table 1, the three bacterial strains showed resistance to at least eight antibiotics out of eleven antibiotics, strain one showed resistance to nine antibiotics, strain two-showed resistance to ten antibiotics and strain threeshowed resistance to eight antibiotics.

This antibiotic resistance could be developed by bacterial strains for various reasons, but the most important reason was antibiotic abuse whether by unnecessary use by patients or by consuming the wrong dose or type. knowing that bacteria is a prokaryotic organism, so genetic mutations that enable bacteria to adapt the environmental conditions are happening frequently and could be another reason for developing antibiotic resistance.

Antibacterial Activity of 21 Medicinal Plant Methanolic Extracts Against MDR E coli:

As shown in table 2, the result of 11 medicinal plant methanolic extracts against three different MDR E. coli bacterial strains, fennel seed methanolic extract showed antibacterial activity towards the three studied bacterial strains, but pomegranate peel showed the biggest inhibition zone on only two bacterial strains.

Table 1: Antibiotics sensitivity pattern of 3 MDR E coli strains tested by 11 antibiotics.

\begin{tabular}{|l|c|c|c|c|c|c|c|c|c|c|c|}
\hline Antibiotic & MEM & GM & MFX & TMN & LVX & OFX & TS & CTX & CIP & AUG & SXT \\
\hline Strain 1 & S & S & R & R & R & R & R & R & R & R & R \\
\hline Strain 2 & S & R & R & R & R & R & R & R & R & R & R \\
\hline Strain 3 & S & R & R & R & R & R & R & S & R & S & R \\
\hline
\end{tabular}




\section{Dina M. Baraka et al.}

Table 2: Antimicrobial activity pattern of three MDR E coli strains affected by ( $6 \mathrm{~mm}) 11$ disks loaded with 11 medicinal plant methanolic extracts

\begin{tabular}{|c|c|c|c|c|c|}
\hline Plant name & Scientific name & Plant part & Strain 1 & Strain 2 & Strain 3 \\
\hline Ginger & $\begin{array}{l}\text { Zingiber } \\
\text { officinale }\end{array}$ & root & $\mathrm{N}$ & $\mathrm{N}$ & $\mathrm{N}$ \\
\hline Cinnamon & $\begin{array}{c}\text { Cinnamomum } \\
\text { verum }\end{array}$ & bark & $\mathrm{N}$ & $\mathrm{N}$ & $\mathrm{N}$ \\
\hline Thyme & Thymus vulgaris & $\begin{array}{l}\text { leaves, } \\
\text { flowers }\end{array}$ & $\mathrm{N}$ & $\begin{array}{l}\text { P } \\
\text { IhZ: } 0.3 \mathrm{~cm}\end{array}$ & $\begin{array}{l}P \\
\text { IhZ: } 0.4 \mathrm{~cm}\end{array}$ \\
\hline Sage & Salvia officinalis & leaves, stem & $\mathrm{N}$ & $\begin{array}{l}\text { P } \\
\text { IhZ: } 0.4 \mathrm{~cm}\end{array}$ & $\begin{array}{l}P \\
\text { IhZ: } 0.2 \mathrm{~cm}\end{array}$ \\
\hline Rosemary & $\begin{array}{l}\text { Salvia } \\
\text { rosmarimus }\end{array}$ & leaves, stem & $\mathrm{N}$ & $\mathrm{N}$ & $\mathrm{N}$ \\
\hline Fennel & $\begin{array}{c}\text { Foeniculum } \\
\text { vulgare }\end{array}$ & bulb, leaves & $\begin{array}{l}\mathrm{P} \\
\mathrm{IhZ}: 0.4 \mathrm{~cm}\end{array}$ & $\begin{array}{l}\mathrm{P} \\
\mathrm{IhZ}: 0.5 \mathrm{~cm}\end{array}$ & $\begin{array}{l}\mathrm{P} \\
\mathrm{IhZ}: 0.4 \mathrm{~cm}\end{array}$ \\
\hline pomegranate & Punica granatum & fruit peel & $\begin{array}{l}\mathrm{P} \\
\mathrm{IhZ}: 0.6 \mathrm{~cm}\end{array}$ & $\mathrm{~N}$ & $\begin{array}{l}\text { P } \\
\text { IhZ: } 0.7 \mathrm{~cm}\end{array}$ \\
\hline Green tea & $\begin{array}{l}\text { Camellia } \\
\text { sinensis; }\end{array}$ & leaves & $\begin{array}{l}\mathrm{P} \\
\mathrm{IhZ}: 0.3 \mathrm{~cm}\end{array}$ & $\mathrm{~N}$ & $\begin{array}{l}P \\
I h Z: 0.2 \mathrm{~cm}\end{array}$ \\
\hline Tumeric & Curcuma longa & root & $\mathrm{N}$ & $\mathrm{N}$ & $\mathrm{N}$ \\
\hline clove & $\begin{array}{c}\text { Syzygium } \\
\text { aromaticum }\end{array}$ & flower buds & $\mathrm{N}$ & $\mathrm{N}$ & $\mathrm{N}$ \\
\hline Black seed & Nigella sativa & seeds & $\mathrm{N}$ & $\mathrm{N}$ & $\mathrm{N}$ \\
\hline
\end{tabular}

IhZ: inhibition zone.

\section{Conclusion:}

This study aimed to find alternative materials that could affect multidrugresistant $E$. coli bacteria which were confirmed as MDR after were tested by eleven antibiotics, bacterial strains were affected by methanolic extracts of eleven medicinal plants and found that fennel seed extract has affected all of the three strains, however, pomegranate fruit peel showed the most powerful extract with biggest inhibition zone. Fennel seed extract can be used as an effecting remedy against $E$. coli bacteria that no longer respond to Antibiotics or even a safe choice before trying antibiotics medication.

\section{REFERENCES}

Aneja, K. R., Joshi, R., Sharma, C., \& Aneja, A. (2010): Antimicrobial efficacy of fruit extracts of two Piper species against selected bacterial and oral fungal pathogens. Brazilian Journal of Oral Sciences, 9(4), 421-426.

Clinical and Laboratory Standards Institute (CLSI) (2007): formerly NCCLS) Performance standards for antimicrobial susceptibility testing seventeen informational supplement.vol.27. (1), pp.26. 3 
Cowan. M.M. (2009): Plant products as antimicrobial agents. Clinical microbiology reviews, vol.12, pp.564-582.

Jain, S., Self, W. H., Wunderink, R. G., Fakhran, S., Balk, R., Bramley, A. M., ... \& Finelli, L. (2015): Community-acquired pneumonia requiring hospitalization among US adults. New England Journal of Medicine, 373(5), 415-427.

Jastaniah S. D. (20140; The antimicrobial activity of some plant extracts, commonly used by Saudi people, against multidrug-resistant bacteria. Life Science Journal, 11(8): $78-84$

Jp, N. (1998). Kape JB. Diarrheagenic Escherichia coli. Clin Microbiol Rev, 11(1), 142-201.].

Kaper, J. B., Nataro, J. P., \& Mobley, H. L. (2004): Pathogenic Escherichia coli. Nature reviews Microbiology, 2(2), 123-140.

Kokoska, L., Polesny, Z., Rada, V., Nepovim, A., \& Vanek, T. (2002):
Screening of some Siberian medicinal plants for antimicrobial activity. Journal of ethnopharmacology, 82(1), 51-53. Mahmoud, Y. A., EBRAHIM, M., \& Aly, M. M. (2004): Influence of some plant extracts and microbioagents on some physiological traits of faba bean infected with Botrytis fabae. Turkish Journal of Botany, 28(6), 519-528.

Palaniappan, K., \& Holley, R. A. (2010): Use of natural antimicrobials to increase antibiotic susceptibility of drug-resistant bacteria. International journal of food microbiology, 140(2-3), 164-168.

Sligl, W., Taylor, G., \& Brindley, P. G. (2006): Five years of nosocomial Gram-negative bacteremia in a general intensive care unit: epidemiology, antimicrobial susceptibility patterns, and outcomes. International Journal of infectious diseases, 10(4), 320325. 